\title{
JUURNAL.RU
}

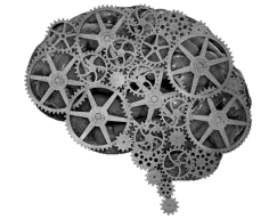

COMPANY GROUP "INTELLEKT"

Киреева А.Н., Сальникова Е.В., Осипов А.А., Харисова К.О. Оренбургский Государственный Университет Оренбург, Россия

doi: 10.18411/lj2016-3-84

\section{Содержание эссенциального элемента цинка в питьевых водах Центрального Оренбуржья}

\section{Аннотация}

B статье приведень результаты исследования по определению содержания эссенциального элемента цинка в питьевых водах Центральной зоны Оренбуржья атомно-адсорбционным методом.

Ключевые слова: цинк, вода, здоровье населения.

Keywords: zinc, water, health

Вода необходима живым организмам, хотя она не имеет питательной ценности. Наш организм состоит на $50-86 \%$ из воды (86\% у новорожденных детей и до 50\% у пожилых людей). В печени человека воды примерно 69\%, в мышцах 70\%; мозг содержит - до 75\%, почки - 82\%, кровь $-85 \%$, кости - 20$30 \%$.

Люди используют воду для питья и пищи, для личной гигиены. Для любого человека вода является самым ценным и незаменим природным богатством [1].

В настоящее время проблему воды следует считать одной из главных проблем охраны окружающей среды, так как вода это не только здоровье населения, но и жизнь животного и растительного мира. 
Микроэлементами в природных водах называются химические элементы, которые содержатся в очень незначительных количествах. К микроэлементам относятся железо, медь, цинк, марганец, йод, селен, кобальт и еще около 40 других элементов. Условно их делят на жизненно необходимые (эссенциальные) и токсичные.

Недостаток в организме жизненно важных микроэлементов, а также избыток токсичных веществ, способствуют нарушению процессов жизнедеятельности, ухудшению здоровья, как отдельных людей, так и населения целых регионов [2].

Цинк - биологически активный эссенциальный элемент для всех форм жизни. Около 2 г цинка содержится в организме человека. Он необходим для функционирования любой клетки организма. Цинксодержащие ферменты присутствуют в большинстве клеток, но их концентрация очень мала и поэтому довольно поздно стало понятно, насколько важен этот элемент. Необходимость и незаменимость цинка для организма человека установлена почти 100 лет тому назад. Суточная норма цинка в питании - 10 - 15 мг [3].

В основном цинк мигрирует в термальных водах вместе со свинцом. Функциональными антагонистами цинка являются медь, кадмий, свинец, особенно на фоне дефицита белка [4].

Большинство жителей Оренбургской области в качестве питьевой воды используют грунтовые воды, не подвергающиеся очистке, имеется дефицит водных источников и их неравноценное распределение. Главными источниками загрязнения поверхностных и подземных вод являются выбросы промышленных предприятий, сточные воды, загрязнение почвы, донные отложения [5].

Всё выше перечисленное делает весьма актуальным в теоретическом и практическом отношениях изучение вопросов, затрагиваемых в данной работе.

Целью исследования является определение содержание эссенциального микроэлемента цинка в питьевых водах Центрального Оренбуржья. 
Объект исследования: питьевые воды Центральной зоны Оренбуржья из источников централизованного водоснабжения.

Метод исследования: атомно - абсорбционный (ГОСТ Р 51232-98) [6].

К Центральной зоне Оренбуржья относятся такие районы как Акбулакский, Александровский, Беляевский, Илекский, Новосергиевский, Октябрьский, Оренбургский, Переволоцкий, Сакмарский, Саракташский, СольИлецкий, Тюльганский и Шарлыкский.

Результаты экспериментов обрабатывали по критерию Стьюдента при уравнении значимости $\mathrm{p}<0,95$ [7].

На рисунке 1 представлены результаты исследования по содержанию эссенциального микроэлемента цинка в питьевых водах Центральной зоны Оренбуржья.

Экспериментальные данные показали, что минимальное содержание цинка в питьевых водах централизованного водоснабжения в следующих районах: в

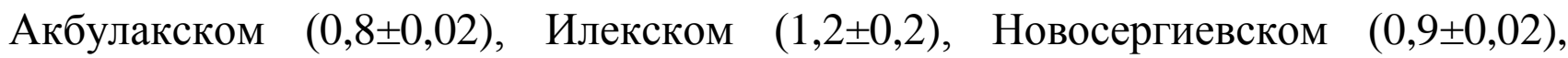
Александровском $(1,8 \pm 0,3)$, Оренбургском $(1,1 \pm 0,2)$, Октябрьском $(0,92 \pm 0,02)$, Тюльганском $(2,1 \pm 0,2)$, Шарлыкском $(1,1 \pm 0,3)$, Соль-Илецком $(1,3 \pm 0,2)$, Сакмарском $(1,4 \pm 0,2), \quad$ Беляевском $(1,78 \pm 2,4), \quad$ Переволоцком $(2,4 \pm 0,3)$, Саракташском $(2,4 \pm 0,2)$ мг/л. В питьевых водах всех выше перечисленных районов содержится цинка от 0,8 до 2,5 мг/л.

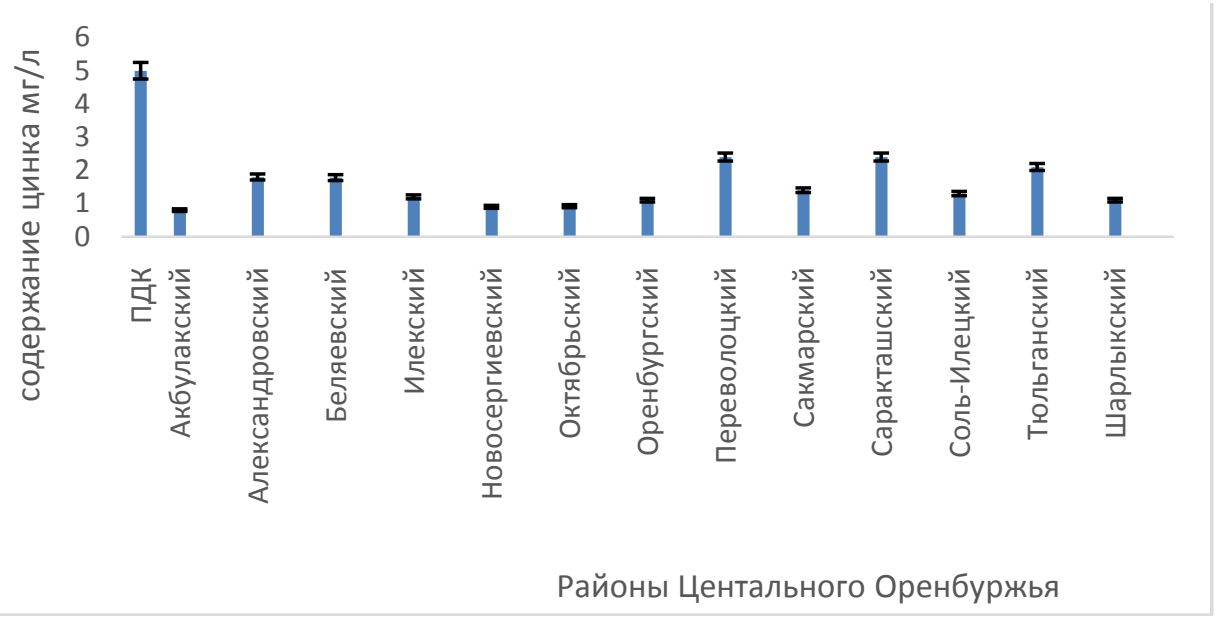

Рисунок 1 - Содержание цинка в питьевых водах Центральной зоны Оренбуржья 
По результатам исследования установлено, что содержание цинка в питьевых водах централизованного водоснабжения во всех рассматриваемых районах Центрального Оренбуржья не превышает ПДК 5 мг/л.

В питьевых водах Акбулакского, Новосергиевского и Октябрьского районов количество цинка в воде незначительное и находится на уровне от 0,8 до 0,92 мг/л. Жителям, проживающим в этих районах необходимо употреблять цинкосодержащие продукты, такие как мясо говядины, морская рыба, устрицы, грибы, тыквенные и подсолнечные семечки, бобы, орехи, молочные продукты, овощи, ягоды и др. В целях профилактики дефицита цинка необходимо принимать витамины или биологически активные вещества, содержащие цинк.

\section{Литература:}

1. Лосев К. С. Вода. — Л.: Гидрометеоиздат, 1989. — 272 с.

2. Авцын А.П., Жаворонков А.А., Риш М.А., Строчкова Л.С. и др. Микроэлементозы человека. Монография. - М.: Медицина, 1991. - 496 с.

3. Скальный А.В. Цинк и здоровье человека. - Оренбург: РИС ГОУ ОГУ, 2003. $-80 \mathrm{c}$.

4. Скальный А.В., Рудаков И.А. Биоэлементы в медицине. - М.: изд. дом «ОНИКС 21 век»: Мир, 2004. - 272 с.

5. Березов, Т. Т. Биологическая химия / Т. Т. Березов, Б.Ф. Коровкин.- М.: Медицина, 1998. - 256 с.

6. ГОСТ Р 51232-98. Вода питьевая. Общие требования к организации и методам контроля качества: введен 17 декабря 1998 г., -21с.

7. Волкова, П. А. Статистическая обработка данных в учебноисследовательских работах / П. А. Волкова, А. Б. Шипунов. - М.: Форум, 2012. $-96 \mathrm{c}$.

8. Сальникова Е.В., Осипова Е.А., Заболотная Н.В. Сравнительная оценка содержания цинка в питьевых водах и почвах Оренбургской области // Вестник ОГУ, № 6 (167)/июнь 2014 155-157 